\title{
Pharmacokinetic study of a new synthetic MMP inhibitor (Ro 28-2653) after IV and oral administration of cyclodextrin solutions
}

\author{
Marie Piette $^{\mathrm{a} 1}$, Brigitte Evrard ${ }^{\mathrm{a}, 1}$, Francis Frankenne ${ }^{\mathrm{b}}$, Patrice Chiap ${ }^{\mathrm{c}}$, Pascal Bertholet ${ }^{\mathrm{a}}$, Delphine Castagne ${ }^{\mathrm{a}}$, \\ Jean-Michel Foidart ${ }^{\mathrm{b}}$, Luc Delattre ${ }^{\mathrm{a}}$, Géraldine Piel $^{\mathrm{a}}$ \\ a laboratory of Pharmaceutical Technology, Department of Pharmacy, University of Liège, CHU, B36, B-4000 Liège 1, Belgium \\ ${ }^{b}$ Laboratory of Biology of Tumors and Development, University of Liège, CHU, B23, B-4000 Liège 1, Belgium \\ ${ }^{c}$ Laboratory of Analytical Pharmaceutical Chemistry, Department of Pharmacy, University of Liège, CHU, B36, B-4000 Liège 1, Belgium
}

\begin{abstract}
Ro 28-2653 (5-biphenyl-4-yl-5-[4-(4-nitro-phenyl)-piperazin-1-yl]-pyrimidine-2,4,6-trione) is a new synthetic inhibitor of matrix metalloproteinases (MMPs) with a high selectivity towards MMP2, MMP9 and membrane type 1-MMP. It has been shown that cyclodextrins (CDs) are able to form inclusion complexes with Ro 28-2653 and to increase its aqueous solubility. The aim of this study is to demonstrate that an increase in Ro 28-2653 solubility, via ternary complex formation, can lead to an increase in the oral bioavailability of this drug. This study shows that a synergistic effect exists between hydroxypropyl- $\beta$-cyclodextrin (HP- $\beta$-CD) and L-lysine. The use of this multicomponent system enabled the preparation of oral and intravenous solutions of Ro 28-2653. In vivo evaluation of the oral solution of the inclusion complex of Ro 28-2653 in comparison with a suspension of the same uncomplexed drug showed a significant $(p<0.05)$ increase in absolute bioavailability. The area undercurve (AUC) and the peak serum concentration $\left(\mathrm{C}_{\max }\right)$ were approximately 10 times higher than those obtained with the suspension, while the time $\left(\mathrm{T}_{\max }\right)$ to reach $\mathrm{C}_{\max }$ was reduced. Moreover, in vivo administration of Ro 28-2653 solutions highlighted some information about the pharmacokinetic behavior of Ro 28-2653: a long biologic half-life (about $15.5 \mathrm{~h}$ ) and a small overall volume of distribution (81).
\end{abstract}

\section{Introduction}

Ro 28-2653 (5-biphenyl-4-yl-5-[4-(4-nitro-phenyl)-piperazin-l-yl]-pyrimidine-2,4,6-trione) (Fig. 1) is a new synthetic inhibitor of matrix metalloproteinases (MMPs) (Grams et al., 2001; Lein et al, 2002; Mangoldt et al., 2002; Noel et al., 2000; Opalka et al., 2002). These enzymes have recently become important in the field of anticancer drug research: they play a crucial and complex role in tumor growth, angiogenesis and formation of metastasis (Egeblad and Werb, 2002; Fingleton, 2003; Overall and Lopez-Otin, 2002; Vihinen and Kahari, 2002). Among the inhibitors of MMPs recently synthesized, Ro 28-2653 presents a high selectivity towards MMP2, MMP9 and membrane type 1-MMP (Grams et al, 2001; Lein et al, 2002; Noel et al., 2000; Opalka et al., 2002). These three MMPs seem to play a major role in tumor development and aggressiveness (Itoh et al., 1998, 1999; Mangoldt et al., 2002; Noel et al., 2004; Sounni et al., 2003; Talvensaari-Mattila et al., 1998). This selectivity may be of interest with regard to increasing efficacy of the drug and to decreasing side effects mainly reported from other MMPs inhibitors, such as musculoskeletal pain (Arlt et al., 2002; Fingleton, 2003; Taraboletti and Margosio, 2001). It has been shown that this promising compound is able to reduce tumor growth in orthotopic prostatic cancer in rats; a significantly prolonged survival of the treated rats was also demonstrated (Lein et al., 2002). In addition, high efficacy in several types of cancer in in vivo models and regarding the drug's antiangiogenic effects have been reported (Noel et al., 2000).

Unfortunately, Ro 28-2653 is a drug that exhibits poor water-solubility. This low solubility (about $0.56 \mu \mathrm{g} / \mathrm{ml}$ in water at $25^{\circ} \mathrm{C}$ ) makes the pharmaceutical formulation of oral or injectable solutions difficult and reduces flexibility in terms of administration (Bertholet et al., 2005). Furthermore, the lack of aqueous solubility may lead to poor and erratic absorption from the gastrointestinal tract and, consequently, low and variable bioavailability may occur. In order to overcome these drawbacks, increasing the aqueous solubility of Ro 282653 is an important goal.

Cyclodextrins (CDs) are cyclic oligosaccharides used in pharmaceutical formulations to enhance solubility, dissolution rate and stability of compounds showing poor water-solubility These changes are caused by complexation of hydrophobic drug molecules or hydrophobic parts of drugs into their apolar cavity (Loftsson

\footnotetext{
${ }^{1}$ These authors contributed equally to this work
} 
and Brewster, 1996; Mosher and Thompson, 2000). Furthermore, in oral drug delivery, CDs can modify the absorption of drugs, thus increasing the bioavailability of active compounds with poor water-solubility (Rajewski and Stella, 1996).

Fig. 1 - Chemical structure of Ro 28-2653.<smiles>O=C1NC(=O)C(c2ccc(-c3ccccc3)cc2)(N2CCN(c3ccc([N+](=O)[O-])cc3)CC2)C(=O)N1</smiles>

Several CDs have been considered for their ability to form inclusion complexes with Ro 28-2653 (Bertholet et al., 2005). Among these cyclodextrins, 2-hydroxypropyl- $\beta$-cyclodextrin (HP- $\beta$-CD) appears to be especially useful, based on its safety for intravenous administration and on its complexation potential (Bertholet et al., 2005; Brewster and Loftsson, 2002; Irie and Uekama, 1997; Ma et al., 1999; Mosher and Thompson, 2000).

Previous studies have already reported a combined effect of CDs and acid or alkaline compounds on the solubility of alkaline or acidic lipophilic drugs, respectively: complexation and simultaneous salt formation allow higher solubility in comparison with simple binary complexes (Redenti et al., 2000, 2001). In some cases, this result is reflected in higher bioavailability (rate and extent of absorption) (Redenti et al., 2001). Aminoacids, such as L-lysine, are often employed to increase the complexation efficiency of CDs with acidic compounds such as Ro 28-2653 (pyrimidine-2,4,6-trione) (Mura et al., 2003; Piel et al., 1997; Redenti et al., 2001).

The objective of this study is to demonstrate that an increase in Ro 28-2653 solubility, via ternary complex formation, can lead to an increase in the oral bioavailability of this drug. Firstly, the solubilizing efficiency of a combination of HP- $\beta-C D$ and L-lysine is studied in order to formulate a parenteral and an oral solution of Ro 282653. Secondly, the pharmacokinetic parameters of Ro 28-2653 are determined after intravenous administration in sheep and in vivo data of the solution, containing the inclusion complex of Ro 28-2653, are compared to those of an aqueous suspension after oral administration.

\section{Materials and methods}

\subsection{Drug and products}

Ro 28-2653 (5-biphenyl-4-yl-5-[4-(4-nitro-phenyl)-piperazin-1-yl]-pyrimidine-2,4,6-trione) was synthesized by SYNTHEVAL (Caen, France). HP- $\beta-C D$ (Kleptose ${ }^{\circledR}$ HPB, D.S. $=0.64$, Eur. Ph. 4th ed.) was kindly given by Roquette (Lestrem, France). A pyrogen-free grade was used for preparing the intravenous solution. L-lysine was supplied by Fluka (Buchs, Switzerland) and water for injection $\left(\right.$ Viaflo ${ }^{\circledR}$ ) by Baxter (Lessines, Belgium). All other products were of analytical or HPLC grade.

\subsection{Solubility studies}

Solubility studies were performed as described by Higuchi and Connors (Higuchi and Connors, 1965). Excess amounts of Ro 28-2653 were added to increasing concentrations of HP- $\beta-C D(0-200 \mathrm{mM})$ in $5 \mathrm{ml}$ dissolution media, either purified water or L-lysine solutions $(50$ or $500 \mathrm{mM})$. The glass containers were sealed and the suspensions shaken in a water-bath at $25^{\circ} \mathrm{C}$ until complexation equilibrium was reached ( 7 days). An aliquot was filtered through a $0.45 \mu \mathrm{m}$ PVDF membrane filter and assayed for Ro 28-2653 content by a validated liquid chromatography (LC) method (Bertholet et al., 2005). The $\mathrm{pH}$ values of the different solutions were recorded at complexation equilibrium. 


\subsection{Dosage form preparations}

The Ro 28-2653/HP- $\beta$-CD intravenous solution was obtained by dissolving Ro $28-2653$ (10mg/ml) in a solution containing HP- $\beta$-CD (200 mM), L-lysine $(20 \mathrm{mM})$ and water for injection.

The osmolality (about $325 \mathrm{mOsmol} / \mathrm{kg}$ ) and the $\mathrm{pH}$ (about 8.2) values of this solution are compatible with an intravenous injection. The solution was sterilized by being passed through a sterile $0.20 \mu \mathrm{m}$ cellulose acetate filter under aseptic conditions.

The Ro 28-2653/HP- $\beta$-CD oral solution was prepared by dissolving Ro $28-2653(15 \mathrm{mg} / \mathrm{ml})$ in a solution containing HP- $\beta$-CD (200 mM), L-lysine $(50 \mathrm{mM})$ and water. The $\mathrm{pH}$ value of this solution was about 9.0.

The Ro 28-2653 suspension was composed of Ro $28-2653(15 \mathrm{mg} / \mathrm{ml})$, with polysorbate $80(0.1 \mathrm{mg} / \mathrm{ml})$ as a wetting agent, together with simaldrate (VEEGUM HV $\left.{ }^{\circledR}, 1 \% \mathrm{~m} / \mathrm{v}\right)$ and methylcellulose (METHOCEL A400 ${ }^{\circledR}$, $0.4 \% \mathrm{~m} / \mathrm{v}$ ) as viscosifying agents.

\subsection{Animal experimental protocol and drug administration}

Six healthy sheep (two males and four females) ranging from 45 to $82 \mathrm{~kg}$ of body weight were used as experimental animals. Sheep were chosen for this preliminary study because of the easiness of both intravenous and oral administration with this species and because of their availability. During the test, the animals were fed and watered ad libitum. The experimental study, which was realized following the scheme of Table 1, included a randomized two-way cross-over design for oral administration followed by intravenous administration. A washout period of 3 weeks was allowed between each administration.

For the oral dosage forms, each animal received an Ro $28-2653$ dose equal to $15 \mathrm{mg} / \mathrm{kg}$ of body weight from both formulations. Sheep were weighed on the day of drug administration in order to adapt the dosage form volume. Blood samples were taken from jugular vein before oral administration and at intervals of 0.25 , $0.5,1,1.5,2,3,4,6,8,10,12,24,28,32,48,72,96,120,144,168 \mathrm{~h}$ afterwards.

For the intravenous dosage form, all six sheep received $5 \mathrm{mg}$ of Ro 28-2653/kg of body weight. The solution was administered through the left jugular vein. Blood samples were taken from the right jugular vein before intravenous administration and at intervals of 5,10,15, 20, 30, $45 \mathrm{~min}, 1,1.5,2,3,4,5,6,8,10,12,24,28,32,48$, $72,96,120,144,168 \mathrm{~h}$ afterwards. All blood samples were centrifuged and the serums were stored at $-80{ }^{\circ} \mathrm{C}$ until assayed.

This animal experimental study was undertaken at the 'Centre d'Economie Rurale' (Marloie, Belgium) and had been approved by its own ethics committee.

Table 1 - Animal experimental design for administration of solutions and suspension containing Ro 28-2653

\begin{tabular}{llll}
\hline Sheep & 1st Phase & 2nd Phase & 3rd Phase \\
\hline 1 & Oral suspension & Oral solution & IV Solution \\
2 & Oral suspension & Oral solution & IV Solution \\
3 & Oral suspension & Oral solution & IV Solution \\
4 & Oral solution & Oral suspension & IV Solution \\
5 & Oral solution & Oral suspension & IV Solution \\
6 & Oral solution & Oral suspension & IV Solution \\
\hline
\end{tabular}

\subsection{Bioanalysis method}

A fully automated method was developed for the LC determination of this compound in serum. Sample clean-up was performed by on-line coupling of a pre-column packed with restricted access material (RAM), namely LiChrospher RP-8 ADS (alkyl diol silica), with the analytical column by means of the column-switching technique. The ADS sorbents belong to the group of internal surface reversed-phase supports and have been applied successfully to the clean-up of biological samples prior to LC analysis (Hubert et al., 1999a; Souverain et al., 2004; Yu and Westerlund, 1997). The operating conditions are described in a previous paper (Chiap et al., 
2005). The method was fully validated according to a novel approach based on accuracy profiles, taking into account the total measurement error (Hubert et al, 1999b, 2003, 2004).

For the bioanalytical study, the dosing range of the method had to be increased to $50 \mu \mathrm{g} / \mathrm{ml}$ due to the high concentrations needing to be determined. A partial revalidation was performed and good results were obtained with respect to response function, trueness, precision, accuracy and linearity.

\subsection{Pharmacokinetics and statistical analysis}

For the intravenous administration study, the pharmacokinetic parameters were determined for each animal using a linear two-compartment model with first-order distribution and elimination (Boroujerdi, 2002). The areas under the curve values $\left(\mathrm{AUCs}_{0-168}\right)$ were calculated by linear trapezoidal rule during the sampling period. The following were calculated using conventional equations associated with compartmental analysis: the AUC extrapolated until infinite values $\left(\mathrm{AUCs}_{0-\infty}\right)$, the total body clearance values $\left(\mathrm{Cl}_{\mathrm{t}}\right)$, the biologic half-life $\left(\mathrm{T}_{1 / 2 \beta}\right)$ and the overall volume of distribution $\left(\mathrm{Vd}_{\mathrm{t}}\right)$ (Boroujerdi, 2002).

For the oral administration study, the pharmacokinetic parameters were determined, for each animal and for both suspension and solution, using a linear one-compartment model with first-order input and first-order output (Boroujerdi, 2002). The AUCs $\mathrm{Al}_{0-168}$ were calculated as described above by trapezoidal summation. The AUCs $\mathrm{A}_{0-\infty}$ were estimated by the following equation (Eq. (1)):

$$
\mathrm{AUC}_{0-\infty}=\mathrm{C}_{0}\left(\frac{1}{\mathrm{~K}}-\frac{1}{k_{\mathrm{a}}}\right)
$$

Where $\mathrm{K}$ and $\mathrm{K}_{\mathrm{a}}$ are, respectively, overall elimination rate constant and absorption rate constant, and $\mathrm{C}_{0}$ is the extrapolated concentration at origin.

The maximum concentrations of drug in plasma $\left(\mathrm{C}_{\max }\right)$ and the corresponding times $\left(\mathrm{T}_{\max }\right)$ were determined for each animal by two different means: directly from the concentration-time graphs $\left(\mathrm{C}_{\max }\right.$ experimental and $\mathrm{T}_{\max }$ experimental $)$ and by calculation using the following equations (Eqs. (2) and (3)) $\left(\mathrm{C}_{\text {max calculated }}\right.$ and $\left.\mathrm{T}_{\max \text { calculated }}\right)$ :

$$
\begin{aligned}
& C_{\text {max calculated }}=C_{0}\left(e^{-K T_{\max }}-e^{-k_{\mathrm{a}} T_{\max }}\right) \\
& \mathrm{T}_{\text {max calculated }}=\frac{2.303}{k_{\mathrm{a}}-\mathrm{K}} \log \frac{k_{\mathrm{a}}}{\mathrm{K}}
\end{aligned}
$$

Absolute bioavailability $\left(\mathrm{F}_{\mathrm{absol}}\right)$ was evaluated using the following relation (Eq. (4)):

$$
F_{\text {absol }}=\frac{\mathrm{AUC}_{\text {oral }} D_{\mathrm{IV}}}{\mathrm{AUC}_{\mathrm{IV}} \mathrm{D}_{\text {oral }}}
$$

Where $\mathrm{D}_{\text {oral }}$ and $\mathrm{D}_{\mathrm{IV}}$ are the oral and IV administered drug quantities, respectively.

All pharmacokinetic parameters were reported as means \pm standard deviations except absolute bioavailability, calculated from average $\mathrm{AUC}_{0^{-} \infty}$.

Data were regarded as aberrant when the individual AUC value was higher or lower than mean \pm 2 standard deviations. For this reason, one sheep was excluded from the determination of pharmacokinetic parameters after the oral solution administration and from statistical analysis.

The comparison of pharmacokinetic parameters for the two oral dosage forms was performed with a two-way analysis of variance (two-way ANOVA). After log-transformation in order to normalize the distribution, the mean values of each calculated parameter were compared. Results were considered to be significant at the $5 \%$ critical level $(p<0.05)$. 


\section{Results and discussion}

\subsection{Solubility studies}

It has already been shown by Bertholet et al. that several CDs $(\beta-C D,-\gamma-C D$ and derivatives, such as randomlymethylated- $\beta$-CD (Rameb) and HP- $\beta-C D$ ) are able to form inclusion complexes with Ro 28-2653 and to increase its aqueous solubility. The best results were obtained with Rameb and HP- $\beta-C D$. A $200 \mathrm{mM}$ Rameb or HP- $\beta-C D$ solution, respectively, increased the aqueous solubility of Ro $28-2653$ by about 24,000 and 10,000 times at $37^{\circ} \mathrm{C}$ (Bertholet et al., 2005).

Being safe for intravenous administration, HP- $\beta-C D$ was chosen for the present study. Fig. 2 shows the phase solubility diagram of Ro $28-2653$ obtained at $25{ }^{\circ} \mathrm{C}$ in the presence of HP- $\beta-\mathrm{CD}$ in purified water, in a $50 \mathrm{mM}$ L-lysine solution and in a $500 \mathrm{mM}$ L-lysine solution. In the three cases, the aqueous solubility of Ro 28-2653 increased as a function of CD concentration. The solubility diagram obtained in the absence of L-lysine confirms the previously mentioned results: the solubility of Ro $28-2653$ in a $200 \mathrm{mM}$ HP- $\beta$-CD solution was approximately $5.5 \mathrm{mg} / \mathrm{ml}( \pm 11 \mathrm{mM})$, which corresponds to a 10,000 times increase in Ro $28-2653$ aqueous solubility.

In the presence of L-lysine, Ro 28-2653 solubility in HP- $\beta$-CD solutions was even higher. Solubility in a 200 $\mathrm{mM}$ HP- $\beta-C D$ solution was increased by about two and seven times in the presence of 50 and $500 \mathrm{mM}$ of Llysine, respectively. Table 2 shows solubility data of Ro 28-2653 in the different media and $\mathrm{pH}$ values of the solutions obtained at equilibrium. Results show a synergistic effect between L-lysine and HP- $\beta$-CD. Solubility in the presence of both $500 \mathrm{mM}$ L-lysine and $200 \mathrm{mM} \mathrm{HP}-\beta-\mathrm{CD}(38.14 \mathrm{mg} / \mathrm{ml})$ was higher than had been expected by adding separately the effect of HP- $\beta-C D$ and L-lysine $(5.53$ and $0.09 \mathrm{mg} / \mathrm{ml})$. This synergistic effect between L-lysine and HP- $\beta$-CD allowed a significant increase in Ro 28-2653 aqueous solubility (70,000 times with 500 $\mathrm{mM}$ of L-lysine and $200 \mathrm{mM}$ of HP- $\beta-\mathrm{CD}$ ). The Ro 28-2653 solubility increased with L-lysine concentration and consequently with $\mathrm{pH}$ value. In fact, the increase in Ro 28-2653 aqueous solubility was probably due to synergistic effect between cyclodextrin and $\mathrm{pH}$ obtained with L-lysine at equilibrium.

Solutions for the pharmacokinetic studies were developed with a combination of HP- $\beta$-CD and L-lysine, allowing a high Ro 28-2653 concentration with a biocompatible $\mathrm{pH}$ value. Concentrations are given in Section 2.3 above.

Fig. 2 - Phase solubility diagram of Ro 28-2653 with HP- $\beta$-CD in purified water (•), L-lysine 50mM (×) or Llysine $500 \mathrm{mM}(\mathbf{\Delta})(n=3)$.

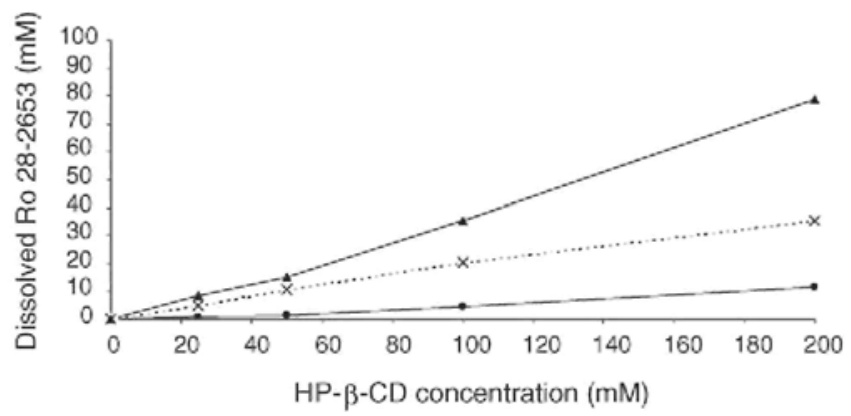

Table 2 - Solubility of Ro 28-2653 ( $\mathrm{mg} / \mathrm{ml})$ in purified water and in L-lysine (50 and $500 \mathrm{mM})$ without or with $H P-\beta-C D(200 \mathrm{mM})$ and $p H$ values of the corresponding solutions

\begin{tabular}{|c|c|c|c|c|}
\hline & \multicolumn{2}{|c|}{ Without CD } & \multicolumn{2}{|c|}{ With HP- $\beta-C D(200 \mathrm{mM})$} \\
\hline & Drug solubility $(\mathrm{mg} / \mathrm{ml})$ & $\mathrm{pH}$ value & Drug solubility $(\mathrm{mg} / \mathrm{ml})$ & $\mathrm{pH}$ value \\
\hline Purified water & About $0.56 \times 10^{-3}$ & - & 5.53 & - \\
\hline L-lysine (50 mM) & 0.05 & 9.8 & 17.08 & 8.8 \\
\hline L-lysine $(500 \mathrm{mM})$ & 0.09 & 10.0 & 38.14 & 9.8 \\
\hline
\end{tabular}




\subsection{Pharmacokinetics of Ro 28-2653 after intravenous administration}

The mean Ro 28-2653 serum concentration versus time curve obtained after a single administration of the intravenous solution $(5 \mathrm{mg} / \mathrm{kg}$ ) to sheep is reported in Fig. 3a. Fig. 3 b (logarithm of the mean Ro 28-2653 serum concentration versus time curve) shows that Ro 28-2653 pharmacokinetics seem to follow a two-compartment model. The different pharmacokinetic parameters calculated after this intravenous administration are listed in Table 3.

The distribution phase was short (about 30min), showing that Ro 28-2653 is rapidly distributed through the organism. The overall volume of distribution was small (about 81), indicating that Ro 28-2653 distribution could be limited to extracellular fluids and that Ro 28-2653 diffusion into tissues may not be very significant. On the other hand, Ro 28-2653 biologic half-life was shown to be long (about 15.5h), with drug elimination consequently being very slow. Considering its small distribution volume, accumulation in the organism might not be caused by storage, for example, in fat, but possibly through strong binding with proteins or other componentsof plasma. The total body clearance value was also calculated at approximately $358.5 \mathrm{ml} / \mathrm{h}$.

\subsection{Pharmacokinetics of Ro 28-2653 after oral administration of a suspension and a solution}

The mean serum concentration versus time profiles of Ro 28-2653 obtained after oral administration of a single dose (15 mg/kg) of Ro 28-2653 solution and suspension are shown in Fig. 4a. After logarithmic transformation of mean serum concentration, it seemed that the pharmacokinetics after oral administration would follow a onecompartment model (Fig. 4b). The pharmacokinetic parameters are summarized in Table 4.

Table 3 - Ro 28-2653 pharmacokinetic parameters (mean \pm S.D.) obtained after intravenous administration (5 $\mathrm{mg} / \mathrm{kg})$ to sheep $(\mathrm{n}=6)$

\begin{tabular}{l} 
IV Solution \\
\hline $858.11 \pm 211.58$ \\
$858.87 \pm 212.08$ \\
$358.76 \pm 67.47$ \\
$8.18 \pm 2.16$ \\
$15.76 \pm 2.34$
\end{tabular}

Fig. 3 - Mean ( \pm S.D.) Ro 28-2653 serum concentration (a) or logarithm of the mean Ro 28-2653 serum concentration (b) vs. time curve after intravenous administration $(5 \mathrm{mg} / \mathrm{kg})$ to sheep $(n=6)$.

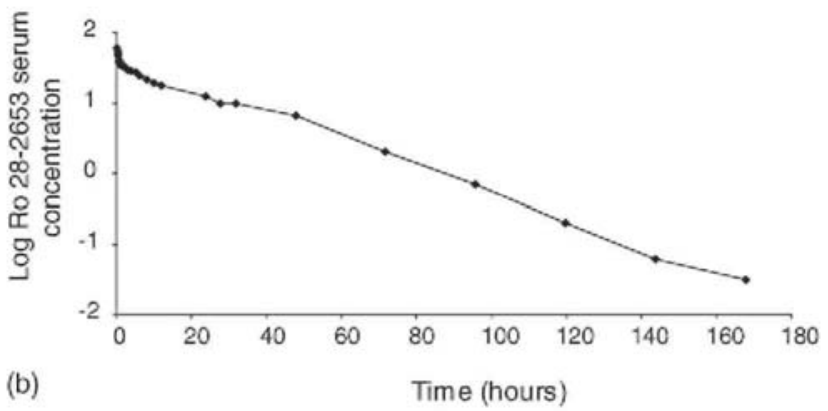


Fig. 4 - Mean ( \pm S.D.) Ro 28-2653 serum concentration (a) or logarithm of the mean Ro 28-2653 serum concentration (b) vs. time curve after oral administration (15 mg/kg) of a solution (A) and a suspension (·) to sheep $(n=5$ for solution and $n=6$ for suspension).
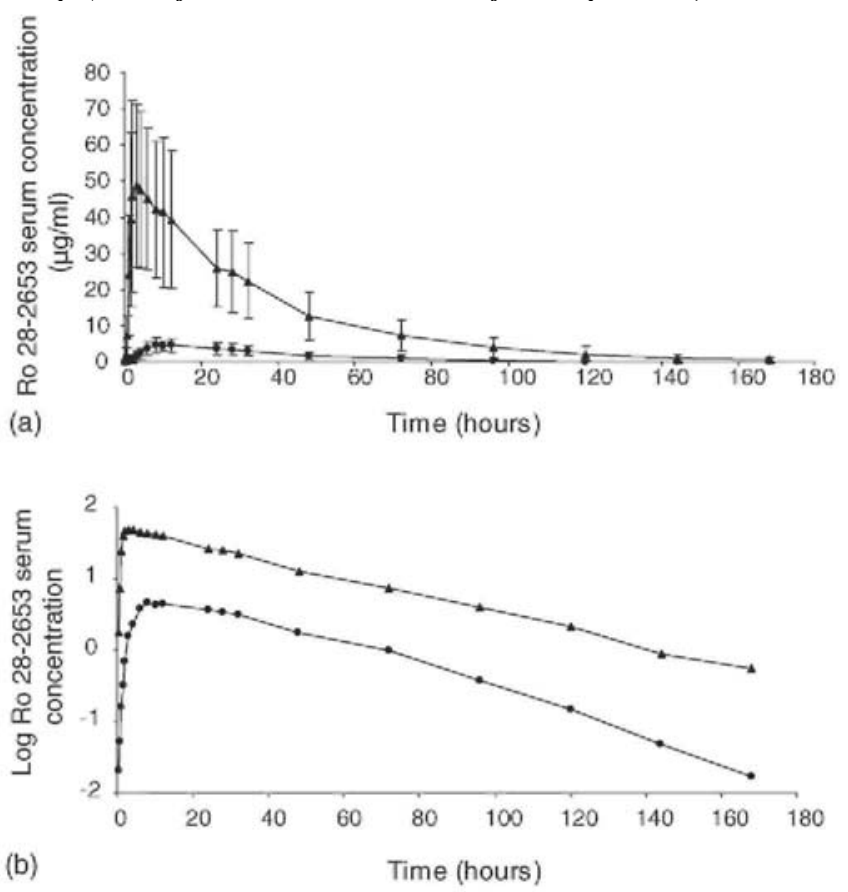

Table4 - Ro 28-2653 Pharmacokinetic parameters(mean \pm S.D., except for F) obtained after oral administration $(15 \mathrm{mg} / \mathrm{Kg})$ to sheep

\begin{tabular}{llll}
\hline & \multicolumn{1}{c}{ Oral solution $(\boldsymbol{n}=\mathbf{5})$} & \multicolumn{1}{c}{ Suspension $(\boldsymbol{n}=\mathbf{6})$} & \multicolumn{1}{c}{$\boldsymbol{p}-$ Value $(\boldsymbol{n}=\mathbf{5})$} \\
\hline $\mathrm{AUC}_{0-168 \mathrm{~h}}(\mu \mathrm{gh} / \mathrm{ml})$ & $1848.66 \pm 854.97$ & $208.94 \pm 103.82$ & 0.0049 \\
$\mathrm{AUC}_{0^{-} \infty}(\mu \mathrm{gh} / \mathrm{ml})$ & $2070.13 \pm 943.79$ & $214.65 \pm 103.04$ & 0.0035 \\
$\mathrm{C}_{\text {max experimental }}(\mu \mathrm{gh} / \mathrm{ml})$ & $51.84 \pm 23.73$ & $4.84 \pm 1.95$ & 0.0009 \\
$\mathrm{C}_{\mathrm{m} \text { ax calculated }}(\mu \mathrm{g} / \mathrm{ml})$ & $56.85 \pm 24.67$ & $5.34 \pm 2.24$ & 0.0010 \\
$\mathrm{~T}_{\text {max experimental }}(\mathrm{h})$ & $3.59 \pm 1.52$ & $12.34 \pm 5.99$ & 0.0094 \\
$\mathrm{C}_{\text {max calculated }}(\mathrm{h})$ & $3.98 \pm 0.57$ & $10.42 \pm 3.01$ & 0.0046 \\
$\mathrm{~F}_{\text {absol }}$ & 0.80 & 0.08 & -
\end{tabular}

The serum concentrations of Ro 28-2653 after administration of the solution were clearly higher than those obtained with an equal dose administered as a suspension. The absorption phase observed with the solution (about 4h) was shorter than that achieved after administration of the suspension (about 10h). It can also be seen that the pharmacokinetic parameters of the solution and the suspension were significantly different $(p<0.05)$ (Table 4). The mean Ro 28-2653 serum peak concentrations were approximately 54 and $5 \mu \mathrm{g} / \mathrm{ml}$ after administration of the solution and the suspension, respectively. $\mathrm{C}_{\max }$ of the solution was about 10 times higher than that of the suspension. A three times earlier $T_{\max }$ was obtained with the solution (about 3.8h) than with the suspension (about $11 \mathrm{~h}$ ). The AUC values followed the same trend as the $\mathrm{C}_{\max }$ values: the AUCs after administration of the solution were about 10 times higher than those after administration of the suspension. Consequently, after comparison with the IV solution, absolute bioavailability was much higher with the solution $(80 \%)$ than with the suspension $(8 \%)$.

The enhancement of bioavailability was ascribed to the increase in the drug's solubility and was supposed to be caused by the same synergistic effect between cyclodex-trin and $\mathrm{pH}$ obtained with L-lysine at equilibrium. The rapid intestinal absorption of drugs included in a cyclodextrin complex could be explained by the competition between the drug and endogenous lipids of the gastro-intestinal tract (Frijlink et al., 1990). Most drugs will be released from the complex and become available for absorption because of the abundant availability of those endogenous lipids. In view of this increase in absorption and bioavailability, the solution containing cyclodextrin 
would be a safe and very effective way to achieve acceptable blood levels from a lower dose of Ro 28-2653.

In addition, although oral administration of a solution often reduces inter and intra individual variability of absorption, the standard deviation values of the different pharmacokinetic parameters obtained here were large, suggesting an important variability in Ro 28-2653 absorption. This variability may be a problem in determining an effective dose for all individuals of a population.

\section{Conclusions}

In this study, it has been shown that a synergistic effect between L-lysine and HP- $\beta$-CD allows a significant increase in Ro 28-2653 aqueous solubility (70,000 times). The use of this multicomponent system permitted the preparation of oral and intravenous solutions of Ro 28-2653. Consequently, intravenous administration of Ro 282653 is possible with less toxic excipients than when using other usual solubilizing agents as, for example, surfactants. The oral solution also presents some advantages. Absolute bioavailability of this oral solution of Ro 28-2653 was significantly higher (about 10 times) than that obtained with a suspension of the same drug. In addition, this solution was characterized by a higher $\mathrm{C}_{\max }$ and a lower $\mathrm{T}_{\max }$. The solubilization of the drug before oral administration allowed for rapid and more significant gastrointestinal absorption of Ro 28-2653.

Moreover, the in vivo administration of Ro 28-2653 solutions highlighted some information about the pharmacokinetic behavior of this new drug. Ro 28-2653 was shown to be rapidly distributed in the organism, its biologic half-life was long (about 15.5h) and the total volume of distribution very small (about 81).

These new intravenous and oral solutions open new opportunities to test in vivo efficacy of this new MMP inhibitor with regard both to its antitumoral activities and its antiangiogenic properties.

\section{Acknowledgements}

This work was supported by the Ministry of the Walloon Region of Belgium (NANOPHAR research, project no. 115013). The authors are grateful to F. Léonard from the Laboratory of Pharmaceutical Technology for her technical aid during the experimental work.

\section{REFERENCES}

Arlt, M., Kopitz, C, Pennington, C, Watson, K.L., Krell, H.W., Bode, W., Gansbacher, B., Khokha, R., Edwards, D.R., Kruger, A., 2002. Increase in gelatinase-specificity of matrix metalloproteinase inhibitors correlates with antimetastatic efficacy in a T-cell lymphoma model. Cancer Res. 62 (19), 5543-5550.

Bertholet, P., Gueders, M., Dives, G., Albert, A., Barillaro, V., Perly, B.,Cataldo, D., Piel, G., Delattre, L., Evrard, B., 2005. The effect of cyclodextrins on the aqueous solubility of a new MMP inhibitor: phase solubility, ${ }^{1} \mathrm{H}$ NMR spectroscopy and molecular modeling studies, preparation and stability study of nebulizable solutions.

J. Pharm. Pharm. Sci. 8 (2), 164-175, http://www.cspscanada.org.Boroujerdi, M., 2002. Pharmacokinetics, Principles and Applications. McGraw-Hill Companies, New York.

Brewster, M.E., Loftsson, T., 2002. The use of chemically modified cyclodextrins in the development of formulations for chemical delivery systems. Pharmazie 57 (2), 94-101.

Chiap, P., Piette, M., Evrard, B., Frankenne, E, Christiaens, B., Piel, G, Cataldo, D., Foidart, J.M., Delattre, L., Crommen, J., Hubert, P., 2005. Automated method for the determination of a new matrix metalloproteinase inhibitor in ovine plasma and serum by coupling of restricted access material for on-line sample clean-up to liquid chromatography. J. Chromatogr. B: Anal. Technol. Biomed. Life Sci. 817 (1), $109-117$

Egeblad, M., Werb, Z., 2002. New functions for the matrix metalloproteinases in cancer progression. Nat. Rev. Cancer 2 (3), 161-174.

Fingleton, B., 2003. Matrix metalloproteinase inhibitors for cancer therapy: the current situation and future prospects. Expert Opin. Ther. Targets 7 (3), 385-397.

Frijlink, H.W., Eissens, A.C., Schoonen, A.J.M., Lerk, CF., 1990. The effects of cyclodextrins on drug absorption. II. In vivo observations. Int. J. Pharm. 64 (2-3), 195-205.

Grams, F, Brandstetter, H., D'Alo, S., Geppert, D., Krell, H.W., Leinert, H., Livi, V., Menta, E., Oliva, A., Zimmermann, G, 2001. Pyrimidine-2,4,6-triones: a new effective and selective class of matrix metalloproteinase inhibitors. Biol. Chem. 382 (8), $1277-1285$. 
Higuchi, T., Connors, K.A., 1965. Phase solubility techniques. Adv. Anal. Chem. Instrum. 4, 117-212.

Hubert, P., Ceccato, A., Chiap, P., Toussaint, B., Crommen, J., 1999a. Préparation des échantillons d'origine biologique préalable à leur analyse chromatographique. STP Pharma Pratiques 9 (2), 160-180.

Hubert, P., Chiap, P., Crommen, J., Boulanger, B., Chapuzet, E., Mercier, N., Bervoas-Martin, S., Chevalier, P., Grandjean, D., Lagorce, P., Lallier, M., Laparra, M.C., Laurentie, M., Nivet, J.C., 1999b. The SFSTP guide on the validation of chromatographic methods for drug bioanalysis: from the Washington Conference to the laboratory. Anal. Chim. Acta 391 (2), 135-148.

Hubert, P., Nguyen-Huu, J.J., Boulanger, B., Chapuzet, E., Chiap, P., Cohen, N., Compagnon, PA., Dewe, W., Feinberg, M., Lallier, M., Laurentie, M., Mercier, N., Nivet, C, Muzard, G., Valat, L., 2003. Validation des procédures analytiques quantitatives, Harmonisation des démarches. STP Pharma Pratiques 13, 27-64.

Hubert, P., Nguyen-Huu, J.J., Boulanger, B., Chapuzet, E., Chiap, P., Cohen, N., Compagnon, P.A., Dewe, W., Feinberg, M., Lallier, M., Laurentie, M., Mercier, N., Muzard, G., Nivet, C, Valat, L., 2004. Harmonization of strategies for the validation of quantitative analytical procedures: a SFSTP proposal-part I. J. Pharm. Biomed. Anal. 36 (3), 579-586

Irie, T., Uekama, K., 1997. Pharmaceutical applications of cyclodextrins. III. Toxicological issues and safety evaluation. J. Pharm. Sci. 86 (2), $147-162$

Itoh, T, Tanioka, M., Yoshida, H., Yoshioka, T, Nishimoto, H., Itohara, S., 1998. Reduced angiogenesis and tumor progression in gelatinase A-deficient mice. Cancer Res. 58 (5), 1048-1051.

Itoh, T, Tanioka, M., Matsuda, H., Nishimoto, H., Yoshioka, T, Suzuki, R., Uehira, M., 1999. Experimental metastasis is suppressed in MMP-9-deficient mice. Clin. Exp. Metastas. 17 (2), 177-181.

Lein, M., Jung, K., Ortel, B., Stephan, C, Rothaug, W., Juchem, R., Johannsen, M., Deger, S., Schnorr, D., Loening, S., Krell, H.W., 2002. The new synthetic matrix metalloproteinase inhibitor (Roche 28-2653) reduces tumor growth and prolongs survival in a prostate cancer standard rat model. Oncogene 21 (13), 2089-2096.

Loftsson, T., Brewster, M.E., 1996. Pharmaceutical applications of cyclodextrins. I. Drug solubilization and stabilization. J. Pharm. Sci. 85 (10), 1017-1025

Ma, D.Q., Rajewski, R.A., Stella, V.J., 1999. New injectable melphalan formulations utilizing (SBE)(7m)-beta-CD or HP-beta-CD. Int. J. Pharm. 189 (2), 227-234.

Mangoldt, D., Sinn, B., Lein, M., Krell, H.W., Schnorr, D., Loening, S.A., Jung, K., 2002. The novel synthetic inhibitor of matrix metalloproteinases Ro 28-2653 induces apoptosis in Dunning tumor cells. Apoptosis 7 (3), 217-220.

Mosher, G., Thompson, D.O., 2000. Complexation and cyclodextrins. In: Swarbrick, J., Boylan, J.C. (Eds.), Encyclopaedia of Pharmaceutical Technology. Marcel Dekker, New York, pp. 49-88.

Mura, P., Maestrelli, F, Cirri, M., 2003. Ternary systems of naproxen with hydroxypropyl-[beta]-cyclodextrin and aminoacids. Int. J. Pharm $260(2), 293-302$

Noel, A., Maquoi, E., Devy, L., Olivier, F, Roland, G., Tiefenhaler, G., Krell, H.W., Foidart, J.M., 2000. Antitumor and antiangiogenic activities of Ro 28-2653, a synthetic matrix metalloproteinase inhibitor. Clin. Cancer Res. 6, 4524.

Noel, A., Maillard, C, Rocks, N., Jost, M., Chabottaux, V, Sounni, N.E., Maquoi, E., Cataldo, D., Foidart, J.M., 2004. Membrane associated proteases and their inhibitors in tumour angiogenesis. J. Clin. Pathol. 57 (6), 577-584.

Opalka, J.R., Gellerich, F.N., Kling, L., Muller-Beckmann, B., Zierz, S., 2002. Effect of the new matrix metalloproteinase inhibitor Ro-282653 on mitochondrial function. Biochem. Pharmacol. 63 (4), 725-732.

Overall, CM., Lopez-Otin, C, 2002. Strategies for MMP inhibition in cancer: innovations for the post-trial era. Nat. Rev. Cancer 2 (9), 657672.

Piel, G., Pirotte, B., Delneuville, I., Neven, P., Llabres, G., Delarge, J., Delattre, L., 1997. Study of the influence of both cyclodextrins and Llysine on the aqueous solubility of nimesulide; isolation and characterization of nimesulide-L-lysine-cyclodextrin complexes. J. Pharm. Sci. $86(4), 475-80$

Rajewski, R.A., Stella, V.J., 1996. Pharmaceutical applications of cyclodextrins. II. In vivo drug delivery. J. Pharm. Sci. 85 (11), $1142-1169$.

Redenti, E., Szente, L., Szejtli, J., 2000. Drug/cyclodextrin/hydroxy acid multicomponent systems. Properties and pharmaceutical applications. J. Pharm. Sci. 89 (1), 1-8. Redenti, E., Szente, L., Szejtli, J., 2001. Cyclodextrin complexes of salts of acidic drugs. Thermodynamic properties, structural features, and pharmaceutical applications. J. Pharm. Sci. 90 (8), 979-986. 
Published in: European Journal of Pharmaceutical Sciences (2006), vol. 28, iss .3, pp. 189-195 Status: Postprint (Author's version)

Souverain, S., Rudaz, S., Veuthey, J.L., 2004. Restricted access materials and large particle supports for on-line sample preparation: an attractive approach for biological fluids analysis. J. Chromatogr. B: Anal. Technol. Biomed. Life Sci. 801 (2), $141-156$.

Talvensaari-Mattila, A., Paakko, P., Hoyhtya, M., Blanco-Sequeiros, G., Turpeenniemi-Hujanen, T, 1998. Matrix metalloproteinase-2 immunoreactive protein: a marker of aggressiveness in breast carcinoma. Cancer 83 (6), 1153-1162.

Taraboletti, G., Margosio, B., 2001. Antiangiogenic and antivascular therapy for cancer. Curr. Opin. Pharmacol. 1 (4), $378-384$.

Vihinen, P., Kahari, V.M., 2002. Matrix metalloproteinases in cancer: prognostic markers and therapeutic targets. Int. J. Cancer 99 (2), $157-$ 166

Yu, Z., Westerlund, D., 1997. Influence of mobile phase conditions on the clean-up effect of restricted-access media precolumns for plasma samples injected in a column-switching system. Chromatographia 44 (11-12), 589-594. 